\title{
Essential Oils in Beeswax Production by Apis mellifera
}

\section{Renata Leonardo Lomele, Mônica Miyuki Ito \& Ricardo de Oliveira Orsi}

To cite this article: Renata Leonardo Lomele, Mônica Miyuki Ito \& Ricardo de Oliveira Orsi (2016) Essential Oils in Beeswax Production by Apis mellifera, Journal of Essential Oil Bearing Plants, 19:7, 1826-1829, DOI: 10.1080/0972060X.2016.1141064

To link to this article: https://doi.org/10.1080/0972060X.2016.1141064

$$
\text { 曲 Published online: } 14 \text { Dec } 2016 .
$$

Submit your article to this journal $\square$

Џ Article views: 28

View Crossmark data ¿ 


$\begin{array}{ll}\text { Taylor \& Francis } & \text { ISSN Print: 0972-060X } \\ \text { ISSN Online: 0976-5026 }\end{array}$

\title{
Essential Oils in Beeswax Production by Apis mellifera
}

\author{
Renata Leonardo Lomele, Mônica Miyuki Ito, Ricardo de Oliveira Orsi * \\ Center for Education, Science and Technology in Beekeeping Rational (NECTAR). Department \\ of Animal Production, Veterinary Medicine and Animal Sciences University, UNESP, \\ Distrito de Rubião Jr., s/n, Zip Code 18618-000, Botucatu, São Paulo, Brazil \\ Received 14 October 2014; accepted in revised form 23 August 2015
}

\begin{abstract}
This research evaluated beeswax production by Africanized honeybees, using essential oils: citronella, eucalyptus, lemongrass and fennel. The sheets of beeswax received $0.5 \mathrm{ml}$ of each oil, on both sides, and placed in the hive. The measurement of constructed area was analysed weekly and the treatment that had a significant expand was evaluated the effect on population development. The results were compared by ANOVA followed by Tukey Test. Only the treatment with citronella showed beeswax production significantly higher $\left(1090.7 \pm 526.9 \mathrm{~cm}^{2}\right)$ compared to control $\left(590.3 \pm 283.2 \mathrm{~cm}^{2}\right)$, without affecting the population development. The treatments with eucalyptus $\left(806.4 \pm 481.6 \mathrm{~cm}^{2}\right)$, lemon grass $\left(664.0 \pm 666.3 \mathrm{~cm}^{2}\right)$ and fennel $(517.3 \pm$ $648.8 \mathrm{~cm}^{2}$ ) showed no significant differences compared to control.
\end{abstract}

Key words: Beekeeping, citronella, eucalyptus, lemongrass, fennel.

\section{Introduction}

Among the products of bees, wax is extremely important to the nest, representing the raw material to build brood cells of workers, drones and queen, deposit food cells (honey and pollen) and construction of the operculum. The wax layers are produced by the wax glands, which are located ventrally in pairs, the fourth to seventh abdominal segment of worker bees and with the functional cycle directly linked to this caste labor division ${ }^{3,12}$.

The wax production is influenced by factors, such as the number of young bees in the hive (between 14 and 20 days), distribution of free spaces in the nest interior, bees clustering temperature (between 33 and $36^{\circ} \mathrm{C}$ ) and food availability. Therefore, for the beeswax commercial production, the beekeeper must provide ideal conditions to the colony, considering all the factors mentioned above.

The volatile oils, also named essential oils and

*Corresponding authors ( Ricardo de Oliveira Orsi) E-mail: < orsi@fmvz.unesp.br > ethereal oils, are the products obtained from plant parts by physical techniques such as steam distillation and pressure. In general, these oils are complex mixtures of volatile substances, lipophilic, commonly odorous and liquids, known by the scent which characterizes certain plants, such as menthol in mint (Mentha sp).

Several biological functions are attributed to these odoriferous substances, like protection against water loss and increase of the temperature, germination inhibitors and attract pollinators ${ }^{4,7}$. Within this context, the essential oils could also promote the bees grouping in the hive free areas, favoring the increased beeswax production.

The purpose of this study was to evaluate the wax production of Africanized Apis mellifera, using as stimulus essential oils of citronella (Cymbopogon nardus), eucalyptus (Eucalyptus $\mathrm{sp}$ ), lemon grass (Cymbopogon citratus) and fennel (Foeniculum vulgare). 


\section{Material and methods}

The experiment occurred in the apiary of Veterinary Medicine and Animal Science University, UNESP, Botucatu, Center for Education, Science and Technology in Beekeeping Rational (NECTAR), with the coordinates: $22^{\circ} 49$ 'South latitude and $48^{\circ} 24^{\prime}$ 'West longitude, with Cfa climate and 623 meters average altitude.

For the experiment, twenty colonies of Apis mellifera L. africanized were selected, settled in Langstroth model hives. During the experimental period, each hive received weekly, $800 \mathrm{ml}$ of sugar syrup (50\% water $+50 \%$ crystallized sugar) by a "Boardman" feeder.

The climatic data for the experimental period was granted by the Department of Environmental Sciences, Agricultural Sciences University, UNESP, Botucatu. The average values for the climate variables during the evaluation of the wax production were: average temperature of $21.1 \pm$ $2.8^{\circ} \mathrm{C}$, precipitation of $2.8 \pm 9.4 \mathrm{~mm}$, relative moisture of $61.4 \pm 18.1 \%$, solar radiation of $7.0 \pm 3.6$ hours and wind speed of $113.6 \pm 46.7 \mathrm{~km} / \mathrm{h}$.

The wax used to the alveolated blades confection was achieved in Beekeeping Production Area of this Faculty, anteriorly to the trial period.

The essential oils used were purchased from commercial enterprise. For the evaluation of wax production, each side of the beeswax sheets received $0.5 \mathrm{~mL}$ of essential oil with a pipette graduated, at the time of placement the frame in the hive. For repetitions the frame was prepared again. There were five repetitions for each treatment, as follows:

- T1: control, one sheet of beeswax without the essential oil;

- T2: beeswax containing essential oil of eucalyptus (Eucalyptus sp);

- T3: beeswax containing essential oil of fennel (Foeniculum vulgare);

- T4: beeswax containing essential oil of lemon grass (Cymbopogon citratus);

- T5: beeswax containing essential oil of citronella (Cymbopogon nardus).

The measurements were performed weekly in the nest, during the period of July to November 2008 , by measuring the constructed area by the bees, according to the methodology adapted ${ }^{2}$. The frame of each treatment was placed in lateral sup- port with stretched wires, forming $2 \times 2 \mathrm{~cm}$ squares, which were counted, on both sides, to measure the total constructed area by the bees.

In the treatments that a significant increment on the beeswax production was detected, an evaluation of its effect on the population development was performed, selecting in each hive a frame containing posture and/or unsealed brood (located in the center of the nest). This frame had its unsealed brood area evaluated using adapted methods ${ }^{2}$ and then, another frame containing the sheets of beeswax with the essential oil which showed an increase in the wax production $(0.5 \mathrm{ml}$ of oil on each side), was placed next to this frame.

After seven days, the frame was removed again from the hive and its brood area analyzed (unsealed or sealed broods), to evaluate a possible effect on larval development. This stage of the experiment was conducted during the period from March to May, 2009.

The results were compared by ANOVA followed by Tukey Test to check for differences between the means. To evaluate the possible effects of climate variables in the wax production, the Pearson Correlation was used. Statistically different was considered when $\mathrm{P}<0.05^{11}$.

\section{Results and discussion}

The results showed that only treatment with citronella showed a significantly higher wax production $\left(1090.7 \pm 526.9 \mathrm{~cm}^{2}\right)$ compared to control $\left(590.3 \pm 283.2 \mathrm{~cm}^{2}\right)$. The treatments with eucalyptus $\left(806.4 \pm 481.6 \mathrm{~cm}^{2}\right)$, lemon grass $\left(664.0 \pm 666.3 \mathrm{~cm}^{2}\right)$ and fennel $(517.3 \pm 648.8$ $\mathrm{cm}^{2}$ ) did not differ significantly from control $(\mathrm{P}<0.05)$. There were no correlations between climatic variables and wax production during the study period.

Under the conditions of this experiment, after the use of citronella essential oil (Cymbopogon nardus), the increase in the construction of wax by the bees suggests that this compound would not be presenting repellent effect on bees Apis mellifera L., unlike which occurs with other types of insects, such as mosquitoes ${ }^{5}$.

In an experiment about the effect of citronella oil (Cymbopogon winterianus Jowitt) as a repellent on Apis mellifera L., the authors found that bees associate the smell of citronella with the 
sucrose solution provided, not occurring proboscis contraction in response to its odor ${ }^{1}$. The authors further found that the essential oil applied directly on bees did not interfere negatively on their permanence in flowers, suggesting that the citronella has no repellent effect on Apis mellifera L.

Equally, in a test in vitro the citronella extract as a repellent on Apis mellifera L. and also on the passion fruit culture (Passiflora edulis $f$. flavicarpa Deg.), the authors found that citronella was not effective in repelling bees ${ }^{6}$. In this work, the increased of wax production with the use of citronella can be explained by the presence of geraniol, which can also be found in the aggregation pheromone secreted by the Nassanov glands of the worker bees. This pheromone is attractive to bees, and, therefore, could promote an increase in the number of bees on the sheet beeswax.

However, other essential oils like eucalyptus and lemongrass also presented geraniol in its composition and did not show different results than the control group, what could be explained by the low concentration of geraniol present on these essential oils ${ }^{8,9,10}$. Thus, the increase of wax production could be directly related to the concentration of geraniol and other compounds present in the oils.

As the citronella oil presented significantly increased of wax production, was evaluated for its possible toxicity to bees. On the evaluating of the hives population development, can be seen that no significant differences were observed between the unsealed and sealed brood areas for both treatments, the control group and with citronella oil, during the studied period (Table 1).

The average brood area unsealed and sealed in the control group were not significantly different from treatment with essential oil of citronella (Table 1). It can be seen that the use of citronella showed no toxic effect since there was any decrease in the brood area of Africanized Apis mellifera. This fact demonstrates that the citronella essential oil (Cymbopogon nardus) enhances the beeswax production, without presenting negative effects on the Apis mellifera L. population development, which may represents an alternative for beekeepers to increase the wax production in their hives.

\section{Acknowledgments}

FAPESP - Fundação de Amparo à Pesquisa do Estado de São Paulo, for providing research grants (process number 08/53372-4).

Table 1. Unsealed brood area (UA) and sealed brood area (SA), in $\mathrm{cm}^{2}$, of Apis mellifera hives, with or whithout the citronella essential oil The results represent the means and standard deviations

\begin{tabular}{|llll|}
\hline \multicolumn{2}{|c}{ Control } & \multicolumn{2}{c|}{ Citronella } \\
\hline $479.0 \pm 162.0 \mathrm{~A}$ & $512.0 \pm 47.6 \mathrm{~A}$ & $397.0 \pm 44.1 \mathrm{~A}$ & \multicolumn{1}{c|}{ SA } \\
\hline $395.0 \pm 169.6 \mathrm{~A}$ & $302.0 \pm 95.6 \mathrm{~A}$ & $26.1 \pm 64.9 \mathrm{~A}$ & $288.0 \pm 43.2 \mathrm{~A}$ \\
$212.0 \pm 58.9 \mathrm{~A}$ & $228.8 \pm 57.2 \mathrm{~A}$ & $311.0 \pm 96.7 \mathrm{~A}$ & $324.0 \pm 94.8 \mathrm{~A}$ \\
$376.0 \pm 62.7 \mathrm{~A}$ & $408.8 \pm 72.8 \mathrm{~A}$ & $288.0 \pm 135.3 \mathrm{~A}$ & $322.0 \pm 95.2 \mathrm{~A}$ \\
$361.0 \pm 165.5 \mathrm{~A}$ & $288.0 \pm 105.2 \mathrm{~A}$ & $420.0 \pm 141.7 \mathrm{~A}$ & $422.8 \pm 112.0 \mathrm{~A}$ \\
$344.6 \pm 149.9 \mathrm{~A}$ & $348.0 \pm 124.8 \mathrm{~A}$ & $335.4 \pm 112.2 \mathrm{~A}$ & $348.0 \pm 90.8 \mathrm{~A}$ \\
\hline
\end{tabular}

Different letters, in the line, indicate statistical difference compared to control group. $(\mathrm{P}<0.05)$.

\section{References}

1. Abramson, C.I., Wilson, M.K., Singleton, J.B. and Wanderley, P.A. (2006). Citronella is not a repellent to africanized honey bees Apis mellifera L. (Hymenoptera: Apidae). BioAssay. 1: $1-7$. 
2. Al-Tikrity, W.S., Hillmann, R.C., Benton, A.W. and Clarke Jr, W.W. (1971). A new instrument for brood measurement in a honey bee colony. Am. Bee. J. 111(1): 20-26.

3. Barros, A.I.R.N.A., Nunes, F.H.F.M. and Costa, M.M.F. (2009). Manual de boas práticas na produção de cera abelhas: princípios gerais. FNAP-Federação Nacional dos Apicultores de Portugal, Lisboa, Portugal.

4. Fabrowski, F.J., Baker, R.T. (2002). Eucaliptus smithii (Myrtaceae) como espécie produtora de óleo essencial no sul do Brasil. Ph.D. dissertation, Centro de Ciências Agrárias - Universidade Federal do Paraná, Curitiba, Brazil.

5. Labinas, A.M. and Crocomo, W.B. (2002). Effect of java grass (Cymbopogon winterianus Jowitt) essential oil on fall armyworm Spodoptera frugiperda (Lepidoptera, Noctuidae). Acta Sci. 24(5): 1401-1405.

6. Malerbo-Souza, D.T., Charlier, A., Rossil, M.M. and Nogueira-Couto, R.H. (2003). Métodos para atraire repelir a abelha Apis mellifera (L.) em cultura de maracujá amarelo (Passiflora edulis flavicarpa flavicarpa Deg.). Acta Sci. 25(1): 1-8.

7. Simões, C.M.O., Schenkel, E.P., Gosman, G., Mello, J.C.P., Mentz, L.A. and Petrovick, P.R. (2004). Farmacognosia-da planta ao medicamento, 5th Ed. Editora da UFGRS/Editora da UFSC, Porto Alegre/Florianópolis, Brazil.

8. Souza, M.P., Matos, M.E.O., Matos, F.J.A., Machado, M.I.L. and Craveiro, A.A. (1991). Constituintes químicos ativos de plantas medicinais brasileiras. UFC/ Lab. Produtos Naturais, Fortaleza, Brazil.

9. Teske, M. and Trentini, A.M.M. (1997). Compêndio de fitoterapia, 3rd Ed. Herbarium, Curitiba, Brazil.

10. Vitti, A.M.S and Brito, J.O. (2003). Óleo essencial de Eucalipto. IPEF, Instituto de Pesquisas e Estudos Florestais, São Paulo, Brazil.

11. Zar, J.K. (1996). Biostatistical analisys. Prentice Hall, New Jersey, USA.

12. Zovaro, R. (2007). Cera de abelha: beneficiamento, produçãoe utilização, Author Ed. São Paulo, Brazil, 